\title{
Destination Innovativeness Towards Tourism Competitive Advantage
}

\author{
Windi N. R. Wardhani*, Widodo Widodo \\ Department of Management, Faculty of Economics \\ Sultan Agung Islamic University (UNISSULA) \\ Semarang, Indonesia \\ *bilqin.09@gmail.com
}

\begin{abstract}
This article proposes the concept Tourism Competitive Advantage which emphasizes the development of tourism in knowledge quality and destination innovativeness by increasing entrepreneurship learning. The population of this study is the tourism industry in Central Java Province with 200 possessed by the government and private owners. The sampling method used was purposive sampling technique, 120 tourism leaders in Central Java Province. The result showed that 3 proposed hypothesis were supported by empirical data and one hypothesis was not supported. When destination innovativeness increase will enhance competitive tourism and it was supported by empirical data. Knowledge quality which was developed as an antecedent to increase destination competitiveness advantages was not supported by empirical data. This condition is caused by knowledge quality indicators which include adaptable, applicable and expandable have not been carried out intensively, extensively and comprehensively. Knowledge quality has positive influence in destination innovativeness. Entrepreneur learning has positive influence in knowledge quality. The evidence of this model contributes to the theory by extending support for social exchange theory and knowledge management into the context of strategies for tourism marketing and development. This paper initiates a new research agenda of tourism competitive advantage with implication for future research, practice and public policy.
\end{abstract}

Keywords-destination innovativeness, tourism competitive advantage, knowledge quality, entrepreneur learning

\section{INTRODUCTION}

The condition of leisure economy is a trend for the community to switch from buying products to buying "experience". Due to that phenomenon, tourism becomes a very prospective sector to be developed. Tourism is one of the driving forces of business in the sector of service. If the tourism sector is compared to other sectors, tourism has more supporting potentials. The tourism industry triggers an increase in state revenue.

A dynamic global tourism industry shows that destination competitiveness is very important to improve its performance, and can facilitate more effective destination management as well as inform overall sustainable economic development [1]. The attractiveness of a destination is also considered as an amalgamation of tourism products that offer integrated experiences and memories for tourists [1]. Therefore, tourism competitive advantage is something which is strategic and substantive. Competitive advantage is related to the ability of the goal to use available resources, that is, the distribution of resources [2]. Tourism Competitive advantage refers to the ability of a destination to attract and satisfy potential tourists [3].

The Digital era has brought a revolution in interactions where new information, communication, and distribution opportunities are open at the same time, requiring many new tools and solutions now used by the tourism industry. Innovation is considered very important for the industry development to achieve sustainable competitive advantage but innovation in tourism remains a topic that is still being researched and innovation is somewhat underestimated in tourism [4-8]. Research gaps related to innovation in the tourism industry lead to insufficient understanding of important elements of innovation in the tourism business [8]. Destination innovativeness research is a new phenomenon. The tourism industry is different from manufacturing and many other services, and Destination innovativeness must be based, in part or in full, on other points of views and research instruments. Thus, a new methodology must be developed and Destination innovativeness research shall be carried out [9].

Problems of learning entrepreneurship are not only related to entrepreneurs who are learning during the process of exploring and exploiting entrepreneurial opportunities in creating new businesses or existing company management [10]. In short, the way of how the learning process takes place and when learning takes place are very important to understand the entrepreneurial process. Entrepreneurship means a learning process and entrepreneurial theory which need learning theory. The consequence of the increasing organizational learning is the increasing number of individuals behaving proactively. The study of Gaetane Caesens [11], however, recommends that future studies be assessed on individual factors in order to improve overall organizational performance. Thus, learning entrepreneurship is a strategic process in developing organizational performance.

\section{THEORETICAL FOUNDATION AND PREPOSITION DEVELOPMENT}

\section{A. Tourism Competitive Advantage}

Organizations whose sustainable competitive advantage are the results provided by rare, valuable and unique human resources; customer relations and systems that provide organizations with a position of ongoing competition [12]. The basic thinking of creating a competitive strategy starts from how the business will be developed, what exactly is the goal and what policies will be needed to achieve that goal [13]. 
The concept of sustainable development is adopted into the concept of developing sustainable tourism development [14]. Sustainable tourism development is defined as a tourism development process that is oriented to the preservation of resources needed for future development and does not have a negative impact on the development of local culture, but the existence of such cultures must be maintained for future generations [15].

Tourism Competitive advantage refers to the ability of destinations to be more attractive and satisfying the potential tourists [3]. Tourism competitive advantage is the ability of objects and the attraction of tourist destinations to maintain market position, share and keep improving it in the long term [16]. Tourism competitive advantage is the ability of objects and attractiveness of tourist destinations to preserve existing natural capital for future generations [17], create and integrate value-added products which maintain their resources [18] and when referring to competitiveness of tourism destinations must also include the sustainability of local resources to ensure maintenance of long-term success and the achievement of equitable resource returns used to satisfy all stakeholders [19] and competitiveness refers to the ability of tourism destinations to improve high living standards for the surrounding community [15]. In terms of strategic management, the main objective of all processes carried out by the organization is to achieve sustainable competitive advantage [20] as like the development of the tourism sector which administers sustainable competitive advantage for the main goal together with the main variables such as destination value, destination, and tourism destinations that are not owned by other regions and able to become regional tourism identities [21]. The three general dimensions of tourism competitive advantage are the dimensions of attractiveness associated with the ability of destinations to attract and satisfy potential tourists; meanwhile, the economic dimension is related to the ability to change favorable positions into economic benefits with the ultimate goal of increasing the wealth of the local population; and finally the sustainability dimension is related to the long-term sustainability of a destination [16].

Thus, it can be concluded that the tourism competitive advantage is the ability of objects and the attractiveness of tourist destinations in maintaining the sustainability of local resources, creating and integrating value-added products, raising high living standards for surrounding communities and attracting as well as satisfying potential tourists. Tourism Competitive advantages must be economically, ecologically, socially, culturally, and politically sustainable. The indicators in this study are environmental sustainability, the welfare of the surrounding community (social wealth), visitor satisfaction, and attractiveness [15].

\section{B. Destination Innovativeness}

Destination innovativeness is the sustainable competitiveness of destination objects and tourist attractions in addressing the competition as well as in collaborating with similar objects to synergize strategies to attract the flow of tourist visits [22]. The tourism sector and industry must have uniqueness (differentiation) that is not owned by other regions. As the result to build this uniqueness, tourism marketers must have a high strategy and innovative power [23].
In tourism and hotel companies, innovation has proven to be more complex than general management [24]. Hjalager [9] states that innovation in tourism occurs in the form of products / services, processes, managerial, marketing or institutional innovation, yet, there remains little doubt about the relevance of innovation for the survival of tourism and hotel companies [9]. The former researches have so far largely concentrated solely on exploring the innovative capabilities of tourist destination actors, without testing the effect on the importance of innovation as a competitive advantage [24].

The current paradigm shift in the meaning of innovation is connected with the development of product packaging, distribution, marketing and strategy [5]. There are many methods used to classify destination innovativeness but in general it revolves around the emphasis on object design and tourist attraction, market research, advertising and promotion [25]. Destination Innovativeness is an important component in achieving sustainable excellence in the tourism sector for it reflects the important means by which organizations are able to capture new opportunities [26].

Destination Innovativeness reflects the tendency of a tourist destination in supporting new ideas, updates, experimentation, and creative processes which can produce new products, services, or developed playing facilities [24]. Tho et.al [27] define Destination Innovativeness as the willingness of tourism companies to innovate. Destination Innovativeness is defined also as a company's tendency to engage in and support new ideas, novelty, experiments, and creative processes which can produce new products, services, or technological processes [28]. In addition, Destination Innovativeness is generally measured by innovations that occur in tourism namely tourism products / services, processes, managerial, marketing or innovation of tourist destinations [24].

Therefore, it can be concluded that Destination Innovativeness is defined as the willingness of tourist destinations to engage in and support new ideas, novelty, experiments, and creative processes which can produce new products, services, or new technological processes in existing playing facilities (playground). Destination Innovativeness is measured by indicators of assimilation, differentiation, inversion, and integration [29]. The results of Foroudi, Jin et al. [30], stated that the capability of innovation is one of the trigers in achieving sustainable competitive advantage. Due to that, a proposition can be arranged as follows:

P1: Destination innovativeness is developed as an antecedent to increase tourism competitive advantage.

\section{Knowledge Quality}

Knowledge plays an important role in innovation $[31,32]$. Innovation is not possible without proactive resources for cooperation, adequate technology and technological knowledge [33]. Transfer of knowledge is very essential for organizations because it tends to be global in nature to utilize diverse labor costs, expertise, and access to world markets [34]. Knowledge transfer, however, is a very difficult process to achieve and knowledge transfer might fail for reasons ranging from the quality of the relationship between the donor and the recipient group to the characteristics of the knowledge transferred. The transfer of knowledge taking place between groups has relatively higher quality from the knowledge possessed by new members compared to the knowledge that is in a group 
although the decision to receive knowledge from new people is influenced by many factors, such as newcomer accommodation or conflict avoidance modes [34].

In the previous literature on knowledge transfer, it was argued that the higher the quality of knowledge, the more complex it is embedded in the reservoir of knowledge of the company which includes people, tasks, tools, and networks. The complexity of knowledge quality is a source of unique and imitable assets because high-quality knowledge is formed by the process of "learning by doing" in organizations, and the key to its creation is the accumulation of experience and knowledge [35]. High-quality knowledge acquisition is needed for innovation where suppliers and target companies share the same knowledge, while acquiring moderate amount of knowledge is needed for more innovation in fields unknown to supplier companies [36].

New, innovative and useful knowledge for the organization / institution / system shall meet the requirements of quality knowledge [37]. Knowledge that is used repeatedly for the formation of other new knowledge is high-quality knowledge [38]. Knowledge quality is defined as an acquisition of useful and innovative knowledge [39]. Knowledge quality is defined as the extent to which awareness and understanding of ideas, logic, relationships, and appropriate conditions can be used, relevant, valuable for context, and applicably adapted [40]. Knowledge can be innovative for a system or organization, but if that knowledge is not useful for organizational development or new innovation in the organization, then it cannot meet the knowledge quality criteria [41]. Knowledge quality can be concluded as knowledge that is used and has adaptability quality, development quality, and is easy to apply.

Linkages, wealth, and knowledge strategies and processes are used to measure knowledge quality [37]. New, innovative and useful knowledge for the organization / institution / system meets quality knowledge requirements [38]. Knowledge quality is measured by using dimensions of usability and innovation [38]. Adaptability, expandability, and applicability are other important features of quality knowledge [35,42]. Knowledge which cannot be applied by individuals in real life because of its practical use is not quality knowledge. Knowledge quality enables organizations to adapt, develop, and easily apply knowledge in order to enhance effective actions and overcome uncertainties by adjusting their knowledge for flexible, broad and easy situations [40]. Thus, the indicators used in this study are Adaptable, Applicable, Expandable, True, Innovative, and Justified [38]. Knowledge is a competitive instrument in the tourism industry which is greatly important to understand knowledge as a resource and competitive advantage [5]. Therefore, a proposition can be set up as follows.

P2: Knowledge quality is developed as an antecedent to increase tourism competitive advantages.

Knowledge plays an important role in innovation [5]. Innovation in organizations is not possible without the existence of highly qualified human resources, who are proactive towards cooperation and innovation, technology, adequate technological knowledge and market knowledge.

P3: Knowledge quality is developed to support the increase of destination innovativeness

\section{Entrepreneur Learning}

Entrepreneurship is very closely related to innovation because it often involves creating something new or in new ways: new combinations, new production methods, new businesses, new markets and new wealth [21]. The entrepreneurial spirit has an important role in the tourism industry [43]. The importance of entrepreneurship in the tourism industry has been largely underestimated or misunderstood [44] whereas entrepreneurship plays a major role in the development of tourist destinations, and the entrepreneurial figures have not been the subject of adequate research [8]. Cowdean et al. [7] defines entrepreneurship as a learning process derived from experience and innovation. Entrepreneurship describes a new combination process in a company in terms of creating new products, new processes, product quality, new organizational formats and so on to answer market challenges [6]. Entrepreneurship innovation in tourism has become a new approach that was initially ignored in the research agenda and ensures that there is still less research on entrepreneurship in the field of hotel industry and tourism management [5].

Today entrepreneurship is considered a process that focuses on innovation, growth and uniqueness [45]. Since the macroeconomic point of view is used, the literature has shown a positive correlation between innovation, entrepreneurship and economic growth [5-8]. Entrepreneurship is a missing link in economic growth because entrepreneurship is a form of knowledge from academics, universities and forms of commercialization of ideas [43]. Entrepreneurship is very closely related to innovation because it often involves creating something new or in new ways: new combinations, new production methods, new businesses, new markets and new wealth [46]. Entrepreneurship is a factor that supports innovation and an important determinant in the competitiveness of the tourism sector because it promotes the transfer of products [9].

Entrepreneur Learning has been studied since a century ago, and has several learning characteristics which are different from other learnings [47]. Organizational learning has a very positive influence on knowledge sharing behavior [48] Entrepreneurial Learning is one variation of the experiential and cognitive processes used to obtain, maintain, use and share entrepreneurial knowledge [47]. The learning process that explores and exploits existing opportunities enables an entrepreneur to respond to market conditions and determine renewal strategies that will be carried out as a step of innovation [49]. Learning of entrepreneurs can facilitate the development of one's dynamic capabilities in adapting to market changes and making appropriate innovations [50].

A successful entrepreneur has a behavior of willing to share ideas and information with others, receive constructive suggestions and criticism, and provides coaching clinics to other entrepreneurs to form a strong network of cooperation [47]. The results of Ernest's research, Matthew et al. [51] state that entrepreneurial learning aims to enhance creativity, have high innovation power as well as entrepreneurial spirit, and become someone who has the ability to solve problems effectively, to communicate, have networks and become leaders [52].

Many scholars have described tourism as a system rather than industry [44] and include attractions, services, promotions, 
information and transportation as the other side of tourism offerings [53], with retail businesses serving tourists, including tourism destination assets owned and operated by tourism entrepreneurs, of which is an important part of that sector. Therefore, remembering the role of entrepreneurs who might be the key stakeholders of hoteliers or restaurant owners or other stakeholders such as retail business owners and tourism actors, their insights about education for businessmen in the hotel industry and tourism sector are important [54].

Entrepreneur learning in tourism is measured by indicators of creativity, risk-taking opportunities, and understanding a sense of tourism community [44]. Entrepreneur learning can be concluded as a learning process to improve the ability to capture career opportunities, creativity, risk taking and responsibility, and provide the technical and business skills needed to start a business.

Entrepreneur learning involves a series of learning processes and skills such as the ability to recognize the personal opportunities of each individual, the ability to utilize existing abilities by generating new ideas and using the necessary resources, the ability of individuals to create, act, take risks by carrying out new adventures and the ability to think in creative and critical ways [44]. Entrepreneurial activities positively influence the innovation of entrepreneurs in the tourism sector [53]. Entrepreneur learning is also a learning process and knowledge-producing skills [8]. Therefore, a proposition can be arranged as follows:

P4: The increase of entrepreneur learning that is developed will be able to give an effect on the increase of knowledge quality.

\section{RESEARCH METHODOLOGY}

\section{A. Sample}

The population of this study is the tourism industry in Central Java Province with 200 tourism destination. The sampling method used was purposive sampling technique. The sample in this research is 120 tousrism destination owner / leader in Central Java Province.

\section{B. Measurement of Variables}

The entrepreneur learning indicator refers to the Deale study [44] which involves recognizing opportunities, generating new ideas and taking risks. Furthermore, the quality indicator knowledge includes: adaptable, applicable and expandable [38]. Then, destination innovativeness involves assimilation, differentiation, integration [29] while Tourism Competitive advantages include environmental sustainability, social wealth and attractiveness [16].

The variables were measured with questionnaire by using Likert-scale with answer scale of 1 to 5 . The scale represented the rating from 'strongly disagree' to 'strongly agree'. Table 1 shows the results of validity and reliability test and a loading factor value above 0.7 [55] and a minimum reliability value of 0.6 [56]. Therefore, it can be concluded that the instrument has the validity and reliability.

\section{ANALITYCAL RESUltS}

The empirically model test used Structural Equation Modeling. The model indicates that Chi-square $=58.000$ with probability value of 0.204 ; $\mathrm{GFI}=0.928, \mathrm{AGFI}=0.888$ and TLI $=0.986$, while value of RMSEA $=0.037$. The result of the model is a Fit. Based on statistically analysis, the results of this study indicate conformity with the required standard values. As shown in Figure 1 was the results of the Full Analysis Model.

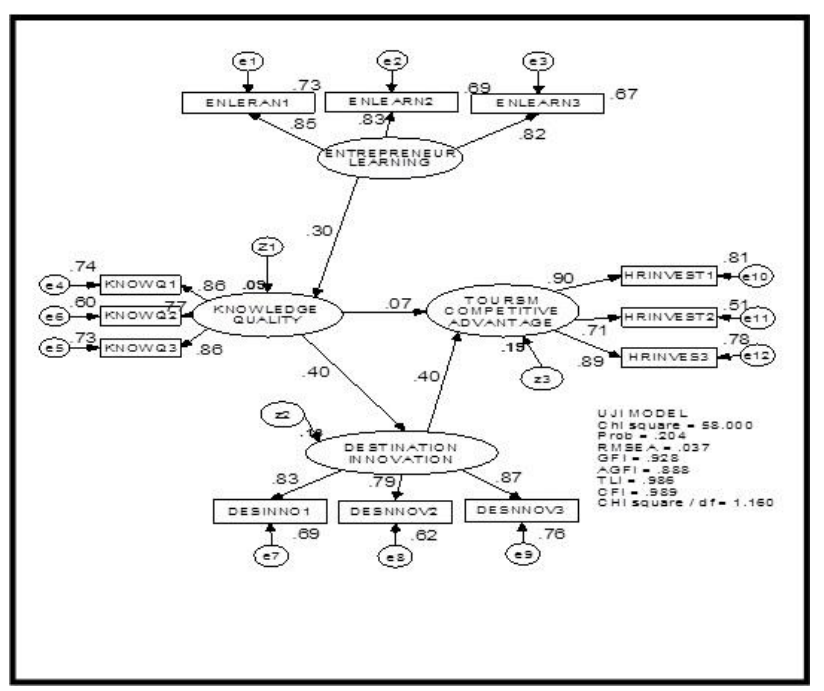

Fig. 1. The results of the full analysis model.

Figure 1 shows that the 3 proposed hypothesis were supported by empirical data and one hypothesis was not supported by empirical data. The first hypothesis proposed was that increasing innovative destinations will enhance competitive tourism and it was supported by empirical data. This condition indicates that the increase in assimilation, differentiation and integration developed will realize environmental sustainability, social wealth and attractiveness. Thus, this supports the study of Foroudi, Jin et al. [30] the capability of innovation is one of the triggers in achieving sustainable competitive advantage. However, the second hypothesis of knowledge quality which was developed as an antecedent to increase destination competitive advantages was not supported by empirical data. This condition is caused by knowledge quality indicators which include adaptable, applicable and expandable have not been carried out intensively, extensively and comprehensively.

The third hypothesis of knowledge quality which is developed will increase destination innovativeness was supported by empirical data. This condition indicates that increasing adaptable, applicable and expandable indicators will trigger an increase in destination innovativeness with assimilation, differentiation and integration indicators. Thus, it supports the opinion of Monteagudo and Maria [5] who say knowledge plays an important role in innovation. Innovation in organizations is not possible without the existence of highly qualified human resources, who are proactive towards cooperation and innovation. Meanwhile, the fourth hypothesis states that increasing entrepreneur learning developed will lead to an increase in knowledge quality was supported by empirical data. This condition shows that entrepreneur learning which is consist of ability to recognize opportunities, produce new ideas and take risks will enhance adaptable, applicable and expandable. Thus, this study supports the opinion of Gjedia and 
Valentina [8] that entrepreneur learning is a learning process and skills which produce knowledge.

The results of the overall hypothesis test are presented in Table 1 as follows.

TABLE I. INNER PATH MODEL COEFFICIENTS AND THEIR SigNIFICANCE

\begin{tabular}{|c|l|l|l|l|}
\hline No & Exogenous variable & $\begin{array}{l}\text { Endogenous } \\
\text { variable }\end{array}$ & $\begin{array}{l}\text { Standard } \\
\text { Estimate }\end{array}$ & T-value \\
\hline 1 & $\begin{array}{l}\text { Tourism Competitive } \\
\text { Advantage }\end{array}$ & $\begin{array}{l}\text { Destination } \\
\text { Innovative }\end{array}$ & 0.403 & $3.648^{*}$ \\
\hline 2 & $\begin{array}{l}\text { Tourism Competitive } \\
\text { Advantage }\end{array}$ & $\begin{array}{l}\text { Knowledge } \\
\text { Quality }\end{array}$ & 0.070 & 0.653 \\
\hline 3 & Destination Innovative & $\begin{array}{l}\text { Knowledge } \\
\text { Quality }\end{array}$ & 0.404 & $3.943^{*}$ \\
\hline 4 & Knowledge Quality & $\begin{array}{l}\text { Entrepreneur } \\
\text { Learning }\end{array}$ & 0.296 & $2.854^{* *}$ \\
\hline
\end{tabular}

$\mathrm{p}<0.05 ; * \mathrm{p}<0.10 ; * * \mathrm{p}<0.01 ; * * * \mathrm{p}<0.001$

The analysis of these direct, indirect and total effects is intended to determine the effects of the hypothesized variables. Direct effect is the coefficient of all coefficient lines with one end arrow or commonly referred to as path coefficient, while indirect effect is the impact caused by intervening variable. Furthermore, the total effect is the total sum of direct and indirect effects. The direct, indirect and total effects of each variable on the Knowledge Quality Development Model towards Entrepreneurship Learning-Based Organizational Performance is presented in table 2 as follows.

TABLE II. DIRECT, INDIRECT AND TOTAL IMPACTS

\begin{tabular}{|c|l|l|c|c|c|}
\hline No & Variable & Effect & $\begin{array}{c}\text { Entrepreneur } \\
\text { Learning }\end{array}$ & $\begin{array}{c}\text { Knowledge } \\
\text { Quality }\end{array}$ & $\begin{array}{c}\text { Destination } \\
\text { Innovation }\end{array}$ \\
\hline 1 & Knowledge & Direct & 0.296 & 0.000 & 0.000 \\
& Quality & Indirect & 0.000 & 0.000 & 0.000 \\
& & Total & 0.296 & 0.000 & 0.000 \\
\hline 2 & Destination & Direct & 0.000 & 0.404 & 0.000 \\
& Innovation & Indirect & 0.120 & 0.000 & 0.000 \\
& & Total & 0.120 & 0.404 & 0.000 \\
\hline 3 & Tourism & Direct & 0.000 & 0.070 & 0.403 \\
& Competitive & Indirect & 0.069 & 0.163 & 0.000 \\
& Advantage & Total & $\mathbf{0 . 0 6 9}$ & $\mathbf{0 . 2 3 2}$ & $\mathbf{0 . 4 0 3}$ \\
\hline
\end{tabular}

Table 2 containing the direct, indirect and total effects of tourism competitive advantage models explains that the knowledge quality is directly influenced by entrepreneur learning at 0.296 while the indirect effect that affects the knowledge quality is not apparent in this research model because the quality knowledge is a variable at the first level in a structured equation model.

The destination innovativeness is directly influenced by knowledge quality with 0.404 while indirect effects which affect destination innovativeness are not seen in this research model because destination innovativeness is the first level variable in structured equation model.

Tourism competitive advantage are directly influenced by quality knowledge (0.070 and destination innovativeness (0.403). It shows that destination innovativeness has a significant influence on tourism competitive advantage while indirect effects of quality knowledge on innovation through destination are 0.163 .

The total effect of entrepreneur learning on tourism competitive advantage is 0.069. Meanwhile, Knowledge quality for tourism competitive advantage is 0.232 . Destination innovativeness regarding tourism has a competitive advantage of 0.403. Based on these total effects, Destination innovativeness towards tourism competitive advantage is $40.3 \%$.

\section{DISCUSSION CONTRIBUTIONS AND IMPLICATIONS}

The developed and expanded knowledge quality has consequences of being able to adapt or being easily applied to tasks. Knowledge must be transformed into action to realize its usefulness and profitability. Unique knowledge is a source of innovative activity. Thus, the possessed quality of knowledge resources must be dynamic in order to realize tourism competitive advantage.

It provides better insight into the potential factors to influence tourism competitive advantage through entrepreneurial learning and knowledge quality and destination innovativeness on non-government and government attractions.

knowledge quality is a key factor in improve the destination innovativeness and it helps to reach the tourism competitive advantagesthis article offer a deeper understanding of important contextual issues which have impacts on efforts to implement strategies of tourism marketing and in turn increase destination competitive advantages. Therefore, the evidence of this model contributes to the theory by extending support for social exchange theory and knowledge management into the context of strategies for tourism marketing and development.

\section{DIRECTION FOR FUTURE RESEARCH}

The calculation results with Software AMOS show that the effect of knowledge quality has no significant effect on tourism competitive advantage. Based on the limitations of the study of antecedent variables, knowledge quality of competitive tourism advantage is an interesting black bock study area. This research, however, has not considered the quality factor of Human Resource of tourism entrepreneurs who are possibly considered to be able to increase their competitiveness / innovativeness on achieving tourism competitive advantage. The addition of environmental support factors or added value can be considered to vary further researches.

\section{CONCLUSION}

The model of developing tourism competitive advantages can be enhanced through destination innovativeness which is built with indicators of assimilation, differentiation and integration. Destination innovativeness is found to have significant relationship with tourism competitive advantage. Knowledge quality is not significant in tourism competitive advantages. This condition is caused by knowledge quality indicators which include adaptable, applicable and expandable have not been carried out intensively, extensively and comprehensively. Knowledge quality has positive influence in destination innovativeness. Eentrepreneur learning has positive influence in knowledge quality.

The evidence of this model contributes to the theory by extending support for social exchange theory and knowledge management into the context of strategies for tourism marketing and development. This paper initiates a new research agenda of tourism competitive advantage with implication for future research, practice and public policy. 


\section{REFERENCES}

[1] W.L. Chin, J. Haddock-Fraser and M.P. Hampton, "Destination competitiveness: evidence from Bali," Current Issues in Tourism, vol. 20, no. 12, pp. 1265-1289, 2017.

[2] G.I. Crouch and J.B. Ritchie, "Tourism, competitiveness, and societal prosperity," Journal of business research, vol. 44, no. 3, pp. 137-152, 1999 .

[3] C.M. Hall, "Constructing sustainable tourism development: The 2030 agenda and the managerial ecology of sustainable tourism," Journal of Sustainable Tourism, pp. 1-17, 2019.

[4] A. Zehrer, B. Muskat and M. Muskat, Innovation in tourism firms. In E. Innerhofer \& H. Pechlaner (Eds.), Competence-Based Innovation in Hospitality and Tourism, pp. 81-94, 2016.

[5] I.C. Monteagudo and M.S.C. Martínez, "Drivers of entrepreneurship innovation in tourism sector: entrepreneurship, KnowleDge anD internationalization," Revista Icade. Revista de las Facultades de Derecho y Ciencias Económicas y Empresariales, no. 94, pp. 11-29, 2015.

[6] D. Politis and J. Gabrielsson, "Modes of learning and entrepreneurial knowledge," International Journal of Innovation and Learning, vol. 18, no. 1, pp. 101-122, 2015.

[7] S. Cowdean, P. Whitby, L. Bradley and P. McGowan, "Entrepreneurial learning in practice: The impact of knowledge transfer," Industry and Higher Education, vol. 33, no. 1, pp. 30-41, 2019.

[8] Gjedia, Robert, and Valentina Ndou, "Educating of Entrepreneurship Competence in Pre-university Education System: An Effective Way for Tourism Development and Innovation," Smart Tourism as a Driver for Culture and Sustainability. Springer, Cham, pp. 35-47, 2019.

[9] A.M. Hjalager, "A review of innovation research in tourismm," Tourism Management, vol. 31, no. 1, pp. 1-12, 2010.

[10] C.L. Wang and H. Chugh, "Entrepreneurial learning: past research and future challenges," Entrepreneurial learning. Routledge, pp. 11-44, 2015.

[11] F. Stinglhamber, G. Marique, G. Caesens, D. Desmette, I. Hansez, D. Hanin and F. Bertrand, "Employees' organizational identification and affective organizational commitment: An integrative approach," PloS one, vol. 10, no. 4, 2015.

[12] S. Kobayashi, Differential geometry of complex vector bundles (Vol. 793). Princeton University Press, 2014.

[13] A. Musetescu, "How to achieve a competitive advantage," Knowledge Horizons. Economics, 5, 13, 2013.

[14] T. Armenski, L. Dwyer and V. Pavluković, "Destination competitiveness: Public and private sector tourism management in Serbia," Journal of travel research, vol. 57, no. 3, pp. 384-398, 2018.

[15] S. Aydin and M. Dube, "Knowledge management, innovation, and competitive advantage: is the relationship in the eye of the beholder?," Knowledge Management Research \& Practice, vol. 16, no. 3, pp. 402-413, 2018.

[16] M. Abreu-Novais, L. Ruhanen and C. Arcodia, "Destination competitiveness: what we know, what we know but shouldn't and what we don't know but should," Current Issues in Tourism, vol. 19, no. 6, 492-512, 2016.

[17] P.P.W. Wong, "Role of components of destination competitiveness in the relationship between customer-based brand equity and destination loyalty," Current Issues in Tourism, vol. 21, no. 5, pp. 504-528, 2015.

[18] T. Al bayrak, M. Caber, M. Rosario González-Rodríguez and A. Aksu, "Analysis of destination competitiveness by IPA and IPCA methods: The case of Costa Brava, Spain against Antalya, Turkey," Tourism Management Perspectives, vol. 28, pp. 53-61, 2018.

[19] J.A. Martínez-Román, J.A. Tamayo, J. Gamero and J.E. Romero, "Innovativeness and business performances in tourism SMEs," Annals of Tourism Research, vol. 54, pp. 118-135, 2015.

[20] Añaña, Edar da Silva, Raphaella Costa Rodrigues, and Luiz Carlos da Silva Flores, "Competitive performance as a substitute for competiveness measurement in tourism destinations: an integrative study." International Journal of Tourism Cities, vol. 4, no. 2, pp. 207 $219,2018$.
[21] Corte Della, Valentina, and Massimo Aria, "Coopetition and sustainable competitive advantage. The case of tourist destinations," Tourism Management, no. 54, pp. 524-540, 2016.

[22] F.J. Zach and T.L. Hill, "Network, knowledge and relationship impacts on innovation in tourism destinations," Tourism Management, vol. 62, pp. 196-207, 2017.

[23] J.K. Fatima, P. Ghandforoush, M. Khan and R. Di Masico, "Role of innovativeness and self-efficacy in tourism m-learning," Tourism Review, 2017.

[24] Kallmuenzer, Andreas, and Mike Peters "Innovativeness and control mechanisms in tourism and hospitality family firms: A comparative study," International Journal of Hospitality Management, vol. 70, pp. 6674, 2018.

[25] de Oliveira Santini, Fernando, Wagner Junior Ladeira, and Claudio Hoffmann Sampaio. "Tourists' perceived value and destination revisit intentions: The moderating effect of domain-specific innovativeness." International Journal of Tourism Research, vol. 20, no. 3, pp. 277-285,

[26] Lee, Kwang-Ho, and Sunghyup Sean Hyun, "The effects of perceived destination ability and destination brand love on tourists' loyalty to postdisaster tourism destinations: The case of Korean tourists to Japan." Journal of Travel \& Tourism Marketing 33.5: 613-627, 2016.

[27] Le, T. V., Zhang, J., Chikaraishi, M., \& Fujiwara, A, Influence of HighSpeed Railway System on Inter-city Travel Behavior in Vietnam. arXiv preprint arXiv:1812.04184, 2018.

[28] Demet, Bagiran Ozseker, "Towards a model of Destination innovativenessprocess: an integrative review," The Service Industries Journal, vol. 39, no. 3-4, pp. 206-228, 2019.

[29] F. Gallouj and M. Savona, Towards a theory of innovation in services: a state of the art. The handbook of innovation and services: A multidisciplinary perspective, pp. 27-48, 2010.

[30] P. Foroudi, Z. Jin, S. Gupta, T.C. Melewar, and M.M. Foroudi, Influence of innovation capability and customer experience on reputation and loyalty. Journal of business research, vol. 69 , no. 11, pp. 4882-4889, 2016

[31] A.M. Hjalager, "Repairing innovation defectiveness in tourism", Tourism Management, vol. 23, no. 1, pp. 465-474, 2002.

[32] B. Lawson and D. Samson, "Developing innovation capability in organizations: a dynamic capabilities approach," International Journal of Innovation Management, vol. 5, no. 3, pp. 377-400, 2011.

[33] Nieves, Julia, and Gonzalo Diaz-Meneses, "Knowledge sources and innovation in the hotel industry: Empirical analysis on Gran Canaria Island, a mature mass-tourism destination," International Journal of Contemporary Hospitality Management, vol. 30, no. 6, pp. 2537-2561, 2018.

[34] P.J. Lane and M. Lutbatkin, "Relative absorptive capacity and interorganizationallearning," Strategic Management Journal, vol. 19, no. 5, pp. 461-477, 1998.

[35] I. Nonaka and H. Takeuchi, "A theory of organizational knowledge creation," International Journal of TechnologyManagement, vol. 11, no. 7-8, pp. 833-845, 1996

[36] Han, John, Gil S. Jo, and Jina Kang, "Is high-quality knowledge always beneficial? Knowledge overlap and innovation performance in technological mergers and acquisitions," Journal of Management \& Organization, vol. 24, no. 2, pp. 258-278, 2018.

[37] W.S. Chow and L.S. Chan, "Social network, social trust and shared goals in organizational knowledge sharing," Information \& management, vol. 45, no. 7, pp. 458-465, 2008.

[38] Waheed, Mehwish, and Kiran Kaur, "Knowledge quality: A review and a revised conceptual model." Information Development, vol. 32, no. 3, pp. 271-284, 2016.

[39] Waheed, Mehwish, Kiran Kaur, and Atika Qazi, "Students' perspective on knowledge quality in eLearning context: a qualitative assessment," Internet Research, vol. 26, no. 1, pp. 120-145, 2016.

[40] Widodo, Sitty Yuwaliatin, Endang Dwi Astuti, "The Development Design of Knowledge quality Based on Knowledge networking and Cross Functional Integration Toward SMES' Innovative Performance," Journal of Applied Economic Sciences (JAES). Volume X, Issue 8 (38), 2015.

[41] S. Liao, C.Y. Chou and T.H. Lin, "Adverse behavioral and relational consequences of service innovation failure," Journal of Business Research, vol. 68, no. 4, pp. 834-839, 2015. 
[42] Dong Kyoon Yoo., Vonderembse, M. A., and Ragu-Nathan, T. S., Knowledge quality: antecedents and consequence in project teams. Journal of Knowledge Management, vol. 15, no. 2, pp. 329-343, 2011.

[43] Hunter, Lise, and Jonathan Lean, "Entrepreneurial learning-a social context perspective: evidence from Kenya and Tanzania," Journal of Small Business and Enterprise Development, vol. 25, no. 4, pp. 609-627, 2018.

[44] C.S. Deale, "Entrepreneurship education in hospitality and tourism: insights from entrepreneurs," Journal of Teaching in Travel \& Tourism vol. 16, no. 1, pp. 20-39, 2016.

[45] W.B. Gartner, "What are we talking about when we talk about entrepreneurship?," Journal of Business venturing, vol. 5, no. 1, pp. 1528, 1990.

[46] C.G. Brush, I.M. Duhaime, W.B. Gartner, A. Stewart, J.A. Katz, M.A Hitt and S. Venkataraman, "Doctoral education in the field of entrepreneurship," Journal of management, vol. 29, no. 3, pp. 309-331, 2003.

[47] K. Ernest, et al., "Towards Entrepreneurial Learning Competencies: The Perspective of Built Environment Students," Higher Education Studies, vol. 5, no. 1, 2015.

[48] Kamya, Moses Tahate, Joseph Mpeera Ntayi, and Augustine Ahiauzu, "Organisational learning and competitive advantage: testing for the interacting influence of knowledge management and innovation," International Journal of Innovation and Learning, vol. 10, no. 4, pp. 376$401,2011$.
[49] Sheng, Margaret L., and Iting Chien, "Rethinking organizational learning orientation on radical and incremental innovation in high-tech firms," Journal of Business Research, vol. 69, no. 6, pp. 2302-2308, 2016.

[50] A. Fernández-Mesa and J. Alegre, "Entrepreneurial orientation and export intensity: Examining the interplay of organizational learning and innovation" International Business Review, vol. 24, no. 1, pp. 148-156, 2015.

[51] Matthew, Ernest, Kissi, Somiah K., and Ansah K. Samuel. "Towards Entrepreneurial Learning Competencies: The Perspective of Built Environment Students," Higher Education Studies, vol. 5, no. 1, pp. 20 30, 2015.

[52] S. Cowdean, P. Whitby, L. Bradley and P. McGowan, "Entrepreneurial learning in practice: The impact of knowledge transfer," Industry \& Higher Education, 2019.

[53] W. Yang, H. Songshan, and S. Gang, "Modelling Chinese consumer choice behavior with budget accommodation services," International Journal of Culture, Tourism and Hospitality Research, vol. 11, no. 3, pp. 341-354, 2017.

[54] H.M. Neck and A.C. Corbett, "The scholarship of teaching and learning entrepreneurship," Entrepreneurship Education and Pedagogy, vol. 1, no. 1 , pp. 8-41, 2018.

[55] U. Sekaran, Research Methods for Business:" A Skill Building Approach, Second Edition, John Willey \& Sons, Inc, 1992.

[56] Jr. Hair, , F. Joseph, R.E. Anderson, R.L. Tatham and W.C. Black, Multivariate Data Analysis with Readings, Macmillan, 1992. 